\title{
Youth Knowledge on the Law of Youth Development in Malaysia
}

\author{
Asmah Laili Yeon, Siti Alida John Abdullah, Rozita Arshad, Zainal Amin Ayub, Alias Azhar, and \\ Safiah Suhaimi
}

\begin{abstract}
This paper examines youth knowledge on the law of youth development in Malaysia. Knowing the law is an added value to youth because they can assist the government in developing youth programmes and activities. This study is a socio-legal study. A survey has been conducted among youth in Malaysia to investigate their awareness on the law of youth development. 267 youths has responded to the survey. The findings show that about $70 \%$ of respondents agree that Malaysia has laws which protect the interest of youth. However, less than $50 \%$ of respondents have knowledge that about the Youth Societies and Youth Development Act 2007 which states main policies relating to youth development. The overall finding shows that less than $60 \%$ respondents are aware about youth policy. It is suggested that more promotion and activities be initiated to improve awareness concerning law and regulations among youth in Malaysia.
\end{abstract}

Index Terms-Knowledge, youth law, youth policy, awareness.

\section{INTRODUCTION}

In 2013, $49 \%$ of the total numbers of citizens of Malaysia are under the category of youth which is equivalent to 13.74 million peoples. The youth age group between 20-24 years old (2.9 million) are the majority in numbers compared to other youth age group. However, the total numbers of youth involvement in youth societies or organization is only $23 \%$ or $3,157,900$ million.

In Malaysia, the principle law governing activities and development of youth is the Youth Societies and Youth Development Act 2007 (YSYDA 2007) [1]. The Act defined youth as a person not less than 15 years and not more than 40 years old. The objective of the Act is to register youth societies, promote and facilitate the development of youth in Malaysia from the aspect of education, research and human resource, to establish a National Youth Consultative Council, to establish the Malaysian Institute for Research in Youth Development and to provide for related matters (Preamble of the Act 2007) [1].

Among the scope of activities involving the youth as stated in section 2 of the YSYDA 2007 includes to build youth character, to develop patriotism, to spread the principles of

Manuscript received September 30, 2014; revised January 29, 2015. This work was supported by the Malaysian Ministry of Education under the NRGS research grant.

Asmah Laili Yeon, Zainal Amin Ayub, and Alias Azhar are with the School of Law, Universiti Utara, Malaysia (e-mail: asmah485@uum.edu.my, z.amin@uum.edu.my, az.alias@uum.edu.my, tuan_nurhafiza@yahoo.com).

Siti Alida John Abdullah, Rozita Arshad, and Safiah Suhaimi are with the School of Government, Universiti Utara, Malaysia (e-mail: alida@uum.edu.my,roz@uum.edu.my,fia_59@yahoo.com).
National Pillars (Rukun Negara) to create the awareness among youth against negative elements and values, to enable youth awareness of culture, the environment, sports, health, spirituality and social welfare. In addition, it is also to provide opportunities for youth participation in urban and rural community development programmes, to provide opportunities for training in leadership, skills and entrepreneurship and to assist the youth to adapt and form positive attitudes in facing the challenges and exigencies of life through the use of educational and life skills components.

\section{LITERATURE REVIEW}

Youth development is defined as "...the ongoing growth process in which all youth are engaged in attempting to (1) meet their basic personal and social needs to be safe, feel cared for, be valued, be useful, and be spiritually grounded, and (2) to build skills and competencies that allow them to function and contribute in their daily lives."(Pittman, 1993) [2].

Youth knowledge is referring to youth access to knowledge and information on the law of youth development. It aims to promote evidence-based policy making and practice, and to enhance the exchange of information (EKCYP, 2012) [3]. Therefore, the output of this research is important in strengthening the law and regulation of youth in Malaysia. Youth awareness on legal knowledge will focuses on youth-centric issues that have legal consequences, their rights and equips youths with the knowledge to distinguish what is right and what is wrong in the eyes of the law.

A distinctive dilemma explored that the absence of a clearly defined legal definition of young people. While young people do exist as a legal category, that category is not clearly defined and young people continue to be widely perceived as a socio-political concept with fuzzy borders and inconsistent interpretations, whereas children are progressively treated and understood as a codified concept with a clear legal status (Robertson and Jones, 2013) [4].

In Malaysia, the principle law governing activities and development of youth is the Youth Societies and Youth Development Act 2007 (YSYDA 2007) [1]. The Act defined youth as a person not less than 15 years and not more than 40 years old. The first legal issue concerning the law of youth in Malaysia is concerning the definition of youth itself. As mentioned above, youth is defined as a person not less than 15 years and not more than 40 years old. According to the Age of Majority Act 1971 (AMA 1971) [5], Section II stated that the minority of all males and females shall cease and determine within Malaysia at the age of 18 years and every 
such male and female attaining that age shall be of the age of majority. It means at the age of eighteen years old, all citizen of Malaysia is considered as adult and they can enter into a legal contract or dealing with any third party but age limitation is not applicable to the following matters namely, marriage, divorce, dower, adoption, religious and religious rites and usage and any provision in any written law contained fixing the age of majority for the specific purpose of that written law (Section IV, AMA 1971) [6].

Thus, the YSYDA 2007 is not in conflict with age limitation provided under the AMA 1971 but according to the United Nation, youth is defined as those between the ages of 15 to 24 years old. Whereas, the Commonwealth defined youth as those between 15 to 29 years old and in the context Indian and African countries, youth is defined as those between 15 to 35 years old (Robertson and Jones, 2013) [3]. Only in Malaysia, the age range has been increased up to 40 years old. It seems to be in Malaysia, the broad definition of youth age includes a large segment of population with different interests, attitudes, needs, skills, education etc.

In the case of Calalang v William G.R. No. 47800. December 2, 1940 [7], Justice Laurel defines social justice as "the promotion of social justice is to be achieved not through a mistaken sympathy towards any given group..... it means the promotion of the welfare of all people, the adoption of the Government measures calculated to ensure economic stability of all the competent elements of society, through the maintenance of a proper economic and social equilibrium in the interrelations of members of the community, constitutionally through the adoption of measures legally justifiable.....". Therefore in designing the policy or law in relations to youth development it must be in line with the philosophy of social justice and equality before the law amongst categories of citizenship in Malaysia. If we analyse the policy and law of youth development, it seems to be in order but in terms of implementation of activities or programmes it will be imbalance if the planning is not proper. For example the age gap of the so-called youth is so wide (15 years old up to 40 years old) resulting in over generalization of programmes and activities for the group as a whole. In the case of employment law, there seems to be a vacuum in terms of protection in law for students of higher education when they undergo their attachment programme with the industry for a period of time e.g. 2 to 6 months. The law does not protect the welfare of trainees or apprentices because provision of allowances, insurance protection, protection from manipulation and discrimination is not provided under the Act etc. (Employment Act 1955) [8]. The importance of this research is to examine to what extent youths know about the law of youth development in Malaysia. Knowing the law is an added value to youth because if they know their rights and policies which is designed for them, they can assist the government in developing youth programmes and activities.

\section{RESEARCH METHODS}

This study is a socio-legal study. Socio-legal study is a research method that brings together two major fields of research in the social sciences and the field of law. Both of these areas are equally important because it examines the relationship between law and society. According to Rohani Abdul Rahim (2002) [3] said that law and society are closely related and difficult to be separated from each other. According to Zahra (1998) [9], legal research is a systematic method of exploring, investigating, analyzing and conceptualizing legal issues pertaining to the enforcement mechanisms and implication of the legal rules and principles. Therefore, this research is a fresh, diligent, systematic, inquiry or investigation of the factual data and theoretical concepts of the rules and principles of youth law.

This study also will adopt two approaches i.e. quantitative and qualitative approaches. For quantitative approach, an exploratory (socio-legal) survey technique using questionnaire has been conducted among youth in Malaysia to investigate their awareness in relations to law of youth development. 267 youths has responded to the survey done by researchers during the State of Kedah Youth Day 2014, National Youth Day Celebration 2014 at Kuala Lumpur and Youth Volunteers Carnival 2014 Putrajaya. For the qualitative approach, the researchers refer to the statutes and decided cases.

The descriptive analysis is carried out with the purpose of stating the rules and principles of the law regarding youth. The purpose of analytical analysis is to investigate deeply, and evaluate every aspect of the factual data in the study. This is important because the researchers can criticize, revise and suggest or propose amendments mechanisms to the rules and regulations and the law relating youth. Primary data from survey was analysed using SPSS version 17 and descriptive statistic was used by the researcher in getting data on frequencies, means and standard deviation.

\section{FINDINGS}

\section{A. Profile of Respondents}

The finding shows that there were 267 respondents (youth) responded to the survey which was distributed to them. $55.4 \%$ were male and 44.6 female.

TABLE I: GENDER

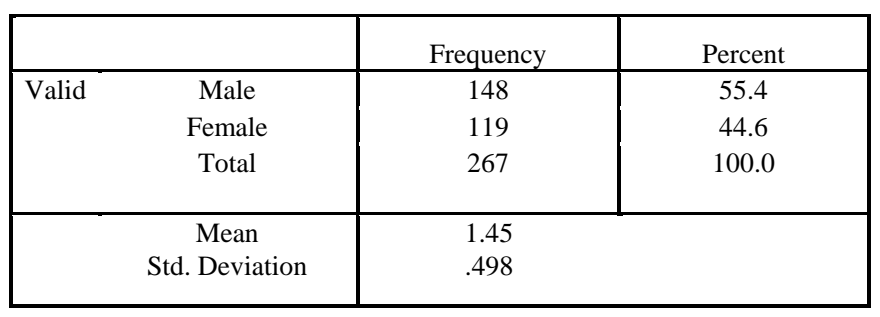

Further, responds from respondents according to age group category are $15-20$ years to the value of $60.7 \%, 21-30$ years is $33 \%$ and $31-40 \%$ is only $6.4 \%$.

TABLE II: AGE

\begin{tabular}{|c|c|c|c|}
\hline & & Frequency & Percent \\
\hline \multirow[t]{4}{*}{ Valid } & \multirow{4}{*}{$\begin{array}{l}\text { 15-20 years old } \\
21-30 \text { years old } \\
31-40 \text { years old } \\
\text { Total }\end{array}$} & 162 & 60.7 \\
\hline & & 88 & 33.0 \\
\hline & & 17 & 6.4 \\
\hline & & 267 & 100.0 \\
\hline
\end{tabular}


TABLE II: AGE

\begin{tabular}{|c|c|c|c|}
\hline & & Frequency & Percent \\
\hline \multirow[t]{3}{*}{ Valid } & $15-20$ years old & 162 & 60.7 \\
\hline & 21-30 years old & 88 & 33.0 \\
\hline & $31-40$ years old & 17 & 6.4 \\
\hline & $\begin{array}{l}\text { Mean } \\
\text { Std. Deviation }\end{array}$ & \multicolumn{2}{|c|}{$\begin{array}{l}1.46 \\
.614\end{array}$} \\
\hline
\end{tabular}

\section{B. Sources of Knowledge}

The respondents were asked about how they know about youth law from different sources such as through their involvement of Ministry of Youth and Sports, youth society activities, mass media and formal education. The highest score is $72.3 \%$ from their involvement in youth society activities, followed by $69.3 \%$ from mass media, $66.6 \%$ activities by the Ministry and $56.9 \%$ from their formal education. Therefore, the Ministry should change the scenario and become the number one disseminator of law knowledge to youths in Malaysia since this effort is one of the function of the Ministry of Youth and Sports.

\section{Knowledge of Respondents on the Law of Youth Development}

Under the YSYDA 2007, it is stated in section 34 of the Act that the policies or directives be made by the Minister of Youth and Sports relating to youth developments are for the following purposes; a) youth knowledge development, b) youth attitude development, c) youth leadership and organisational development, d) youth vocational and entrepreneurial development, e) inculcation of a healthy lifestyle in the youth, $f$ ) facilities for social interaction for the youth, g) youth partnership in development and $h$ ) international relations and networking amongst the youth.

These are the area that should be given priority by the government of Malaysia in general and ministries or authorities which are related to the above agendas in enhancing the development of youth whether in rural or urban areas. The questionnaire is designed in such a way to examine youths' (respondents) awareness and their knowledge about the Act and provisions in the Act.

TABLE III: MALAYSIA HAS LAWS ThAT PROTECT THE INTEREST OF YOUTH

\begin{tabular}{|c|c|c|}
\hline & Frequency & Percent \\
\hline Valid Strongly disagree & 8 & 3.0 \\
\hline \multirow{5}{*}{$\begin{array}{l}\text { Disagree } \\
\text { Not sure } \\
\text { Agree } \\
\text { Strongly Agree } \\
\text { Total }\end{array}$} & 19 & 7.1 \\
\hline & 53 & 19.9 \\
\hline & 101 & 37.8 \\
\hline & 86 & 32.2 \\
\hline & 267 & 100.0 \\
\hline $\begin{array}{l}\text { Mean } \\
\text { Std. Deviation }\end{array}$ & \multicolumn{2}{|c|}{$\begin{array}{r}3.89 \\
1.033\end{array}$} \\
\hline
\end{tabular}

According to the above Table III, the finding of research shows that $70 \%$ of respondents agree Malaysia has laws that protect the interest of youth. However, $10.1 \%$ disagree that Malaysia has laws that protect the interest of youth.

Table IV below shows that $49.1 \%$ know that section 34 of YSYDA 2007 states main policies relating to youth development and only $12.7 \%$ disagree with the above statement.
TABLE IV: KNOWLEDGE ON SECTION 34 OF YOUTH SOCIETIES AND YOUTH DEVELOPMENT ACT 200

\begin{tabular}{|c|c|c|c|}
\hline & & Frequency & Percent \\
\hline \multirow[t]{6}{*}{ Valid } & \multirow{6}{*}{$\begin{array}{l}\text { Strongly disagree } \\
\text { Disagree } \\
\text { Not sure } \\
\text { Agree } \\
\text { Strongly Agree } \\
\text { Total }\end{array}$} & 20 & 7.5 \\
\hline & & 14 & 5.2 \\
\hline & & 102 & 38.2 \\
\hline & & 91 & 34.1 \\
\hline & & 40 & 15.0 \\
\hline & & 267 & 100.0 \\
\hline & $\begin{array}{l}\text { Mean } \\
\text { Std. Deviation }\end{array}$ & \multicolumn{2}{|c|}{$\begin{array}{r}3.44 \\
1.051\end{array}$} \\
\hline
\end{tabular}

Table V below states that $47.2 \%$ of respondents agree that they are fully aware about the policy on youth knowledge development which is provided under the law. While $13.5 \%$ disagree with the statement.

TABLE V: YOUTH KNOWLEDGE DEVELOPMENT

\begin{tabular}{|c|c|c|c|}
\hline & & Frequency & Percent \\
\hline \multirow[t]{6}{*}{ Valid } & \multirow{6}{*}{$\begin{array}{l}\text { Strongly disagree } \\
\text { Disagree } \\
\text { Not sure } \\
\text { Agree } \\
\text { Strongly Agree } \\
\text { Total }\end{array}$} & 11 & 4.1 \\
\hline & & 25 & 9.4 \\
\hline & & 105 & 39.3 \\
\hline & & 89 & 33.3 \\
\hline & & 37 & 13.9 \\
\hline & & 267 & 100.0 \\
\hline & $\begin{array}{l}\text { Mean } \\
\text { Std. Deviation }\end{array}$ & \multicolumn{2}{|c|}{$\begin{array}{l}3.43 \\
.980\end{array}$} \\
\hline
\end{tabular}

$52.8 \%$ of respondent agree that they are fully aware about the policy on youth attitude development, however $10.9 \%$ disagree with it. This is referred to Table VI below.

TABLE VI: YOUTH ATTITUDE DEVELOPMENT

\begin{tabular}{|c|c|c|c|}
\hline & & Frequency & Percent \\
\hline \multirow[t]{6}{*}{ Valid } & Strongly disagree & 4 & 1.5 \\
\hline & Disagree & 25 & 9.4 \\
\hline & Not sure & 97 & 36.3 \\
\hline & Agree & 106 & 39.7 \\
\hline & Strongly Agree & 35 & 13.1 \\
\hline & Total & 267 & 100.0 \\
\hline & $\begin{array}{l}\text { Mean } \\
\text { Std. Deviation }\end{array}$ & \multicolumn{2}{|c|}{$\begin{array}{l}3.54 \\
.889\end{array}$} \\
\hline
\end{tabular}

According to Table VII below, the finding of research shows that $53.2 \%$ agree that they are aware of policy on youth leadership and organizational development but $10.4 \%$ disagree with the statement.

TABLE VII: YOUTH LEADERSHIP AND ORGANIZATIONAL DEVELOPMENT

\begin{tabular}{|c|c|c|c|}
\hline & & Frequency & Percent \\
\hline \multirow[t]{6}{*}{ Valid } & \multirow{6}{*}{$\begin{array}{l}\text { Strongly disagree } \\
\text { Disagree } \\
\text { Not sure } \\
\text { Agree } \\
\text { Strongly Agree } \\
\text { Total }\end{array}$} & 6 & 2.2 \\
\hline & & 22 & 8.2 \\
\hline & & 97 & 36.3 \\
\hline & & 101 & 37.8 \\
\hline & & 41 & 15.4 \\
\hline & & 267 & 100.0 \\
\hline & $\begin{array}{l}\text { Mean } \\
\text { Std. Deviation }\end{array}$ & \multicolumn{2}{|c|}{$\begin{array}{l}3.56 \\
.926\end{array}$} \\
\hline
\end{tabular}

Further, Table VIII below shows that $51.3 \%$ of 
respondents are aware of the policy on youth vocational and entrepreneurial development and $8.2 \%$ disagree with it.

TABLE VIII: YOUTH VOCATIONAL AND ENTREPRENEURIAL DEVELOPMENT

\begin{tabular}{|c|c|c|c|}
\hline & & Frequency & Percent \\
\hline \multirow[t]{6}{*}{ Valid } & \multirow{2}{*}{$\begin{array}{l}\text { Strongly disagree } \\
\text { Disagree }\end{array}$} & 7 & 2.6 \\
\hline & & 15 & 5.6 \\
\hline & \multirow{4}{*}{$\begin{array}{l}\text { Not sure } \\
\text { Agree } \\
\text { Strongly Agree } \\
\text { Total }\end{array}$} & 108 & 40.4 \\
\hline & & 98 & 36.7 \\
\hline & & 39 & 14.6 \\
\hline & & 267 & 100.0 \\
\hline & $\begin{array}{l}\text { Mean } \\
\text { Std. Deviation } \\
\end{array}$ & & \\
\hline
\end{tabular}

The above Table IX shows $58.1 \%$ of respondents are aware of the policy on the inculcation of a healthy lifestyle among youth however, $9.3 \%$ disagree with it.

TABLE IX: INCULCATION OF A HEALTHY LIFESTYLE AMONG YOUTH

\begin{tabular}{|c|c|c|c|}
\hline & & Frequency & Percent \\
\hline \multirow[t]{6}{*}{ Valid } & \multirow{6}{*}{$\begin{array}{l}\text { Strongly disagree } \\
\text { Disagree } \\
\text { Not sure } \\
\text { Agree } \\
\text { Strongly Agree } \\
\text { Total }\end{array}$} & 6 & 2.2 \\
\hline & & 19 & 7.1 \\
\hline & & 87 & 32.6 \\
\hline & & 106 & 39.7 \\
\hline & & 49 & 18.4 \\
\hline & & 267 & 100.0 \\
\hline & $\begin{array}{l}\text { Mean } \\
\text { Std. Deviation }\end{array}$ & \multicolumn{2}{|c|}{$\begin{array}{r}3.65 \\
.936 \\
\end{array}$} \\
\hline
\end{tabular}

Table X below shows that $55.5 \%$ of respondents aware of the policy on facilities for social interaction for the youth and $10.1 \%$ disagree with it.

TABLE X: FACILITIES FOR SOCIAL INTERACTION FOR THE YOUTH

\begin{tabular}{|c|c|c|c|}
\hline & & Frequency & Percent \\
\hline \multirow[t]{6}{*}{ Valid } & \multirow{6}{*}{$\begin{array}{l}\text { Strongly disagree } \\
\text { Disagree } \\
\text { Not sure } \\
\text { Agree } \\
\text { Strongly Agree } \\
\text { Total }\end{array}$} & 4 & 1.5 \\
\hline & & 23 & 8.6 \\
\hline & & 92 & 34.5 \\
\hline & & 103 & 38.6 \\
\hline & & 45 & 16.9 \\
\hline & & 267 & 100.0 \\
\hline & $\begin{array}{l}\text { Mean } \\
\text { Std. Deviation }\end{array}$ & \multicolumn{2}{|c|}{$\begin{array}{l}3.61 \\
.917 \\
\end{array}$} \\
\hline
\end{tabular}

TABLE XI: YOUTH PARTNERSHIP IN DEVELOPMENT

\begin{tabular}{|c|c|c|c|}
\hline & & Frequency & Percent \\
\hline \multirow[t]{6}{*}{ Valid } & \multirow{2}{*}{$\begin{array}{l}\text { Strongly disagree } \\
\text { Disagree }\end{array}$} & 6 & 2.2 \\
\hline & & 15 & 5.6 \\
\hline & \multirow{4}{*}{$\begin{array}{l}\text { Not sure } \\
\text { Agree } \\
\text { Strongly Agree } \\
\text { Total }\end{array}$} & 105 & 39.3 \\
\hline & & 94 & 35.2 \\
\hline & & 47 & 17.6 \\
\hline & & 267 & 100.0 \\
\hline & $\begin{array}{l}\text { Mean } \\
\text { Std. Deviation }\end{array}$ & \multicolumn{2}{|c|}{3.60} \\
\hline
\end{tabular}

TABLE XII: INTERNATIONAL RELATIONS AND NETWORKING AMONGST THE YOUTH

\begin{tabular}{|c|c|c|c|}
\hline & & Frequency & Percent \\
\hline \multirow[t]{6}{*}{ Valid } & \multirow{2}{*}{$\begin{array}{l}\text { Strongly disagree } \\
\text { Disagree }\end{array}$} & 5 & 1.9 \\
\hline & & 23 & 8.6 \\
\hline & \multirow{4}{*}{$\begin{array}{l}\text { Not sure } \\
\text { Agree } \\
\text { Strongly Agree } \\
\text { Total }\end{array}$} & 96 & 36.0 \\
\hline & & 102 & 38.2 \\
\hline & & 41 & 15.4 \\
\hline & & 267 & 100.0 \\
\hline & $\begin{array}{l}\text { Mean } \\
\text { Std. Deviation }\end{array}$ & \multicolumn{2}{|c|}{3.57} \\
\hline
\end{tabular}

According to Table XI, the finding of research shows that $53.6 \%$ of the respondents are aware about the policy on youth partnership in development. Whereas, $10.5 \%$ of the respondents disagree with it.

Table XII below shows that $53.6 \%$ of respondents are aware of the policy on the international relations and networking amongst the youth and $10.5 \%$ of the respondents disagree.

\section{DISCUSSION AND CONCLUSION}

Under section 55 of the YSYDA 2007, one of the functions of Malaysian Institute for Research in Youth Development is to carry out educational and awareness programmes for the promotion of youth development. However, to what extent the Institute plays its role to inculcate knowledge of law to youths in Malaysia. The finding shows that $66.6 \%$ agree that they know about youth law through their involvement in Ministry of Youth and Sports activities. $72.3 \%$ through their involvement in youth society activities, $69.3 \%$ from mass media and $56.9 \%$ from formal education. Therefore, it is important that the Institute under the ministry to upgrade their effort in dissemination of knowledge of youth development law.

In relation to the knowledge of youth on the eight main policies regarding youth development, the overall findings shows that less than $60 \%$ of respondents are fully aware about these eight main policies which signifies the main responsibilities of the Ministry of Youth and Sports and other related ministries in Malaysia in managing youth affairs. Therefore, researchers are of opinion dissemination of information among youth should be enhanced in order to update them with relevant information about law and regulations.

The youth of Malaysia have an important role to play in helping the government of Malaysia to achieve the status of a fully developed country by the year 2020. The Malaysian vision 2020 aims to develop all aspects of the country including national unity, social cohesion, economy, social justice, political stability, system of government, quality of life, social and spiritual values and national pride and confidence. Therefore, all relevant and material information should be disseminated to all youth in Malaysia so that they can participate and contribute to the nation and be smart partners to the government ministries.

\section{REFERENCES}

[1] ILBS, Youth Societies and Youth Developments Act, Kuala Lumpur: ILBS Publications, 2007.

[2] J. P. Karen, R. O'Brien, and M. Kimball, "Youth development and resiliency research: Making connections to substance abuse prevention," Center for Youth Development and Policy Research/Academy for Educational Development, New York, 1993.

[3] EKCYP. (2012). Europe: Knowledge. European Knowledge Centre for Youth Policy (EKCYP). [Online]. Available: http://www.youth-partnership.net/youth-partnership/ekcyp/index

[4] A. Robertson and R. J. Parry, The Commonwealth Yearbook 2013, Commonwealth Secretariat by Nexus Strategic Partnerships, Cambridge, Nexus/Commonwealth Secretariat, 2013.

[5] ILBS, Age of Majority Act 1971, Kuala Lumpur: ILBS Publications, 2007.

[6] Calalang vs. William G. R. No. 47800. (December 2, 1940). [Online]. Available: 
http://elaw.i.ph/blogs/elaw/2008/09/09/calalang.vs-williams-constituti onal-law-digest/9

[7] ILBS, Employment Act 1955, Kuala Lumpur: ILBS Publications, 1955.

[8] R. A. Rahim, "Metodologi penyelidikan undang-undang: Satu tinjauan kepada kajian sosio-perundangan," Kertas Kerja Seminar Kemantapan Akademik UKM, 2002.

[9] M. Zahra. "Research methods for law postgraduate overseas students," Stilglow Sdn. Bhd, Kuala Lumpur, 1998.

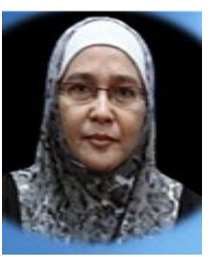

Asmah Laili Yeon was born on March 30, 1965, in Perak, Malaysia. He holds a bachelor's degree of Law International Islamic University Malaysia, in 1989, master degree of Comparative Laws International Islamic University Malaysia, in 1991 and Ph.D in Law University of Aberdeen, United Kingdom, in 1999.

She is an associate professor of the School of Law, Universiti Utara Malaysia. Currently, she is the director of Legal Aid Center of UUM. She started her career at one of the law firm in Malaysia before joining the university in 1990. Currently, she has successfully supervised eight Ph.D students. Her research interests are in the area of securities and derivatives industry law, business law and ethics, company law, corporate governance and employment law and industrial relation. She had received research fund since 1995 until now, from external organization such as the Ministry of Science and Technology, Malaysia previously known as IRPA grant and Ministry of Education, Malaysia through the FRGS, ERGS, RAGS and NRGS Grant and internal source through research funded by the Universiti Utara Malaysia. To date, she had completed 14 research projects and currently she involved with another six research projects as the project leader and researcher funded by the Ministry of Education i.e. RAGS, FRGS and NRGS. The area of current research projects are corruption law, contract of service of academic staff, private retirement scheme law, trade union and industrial relation law, youth law and governance and election law. She had published books, articles journal and presented papers at national and international level. She is the panel member of Malaysian Qualifying Agency, Editorial Board Member of International Journal of Management Studies, International Journal on Graft and Corruption Research and etc. 